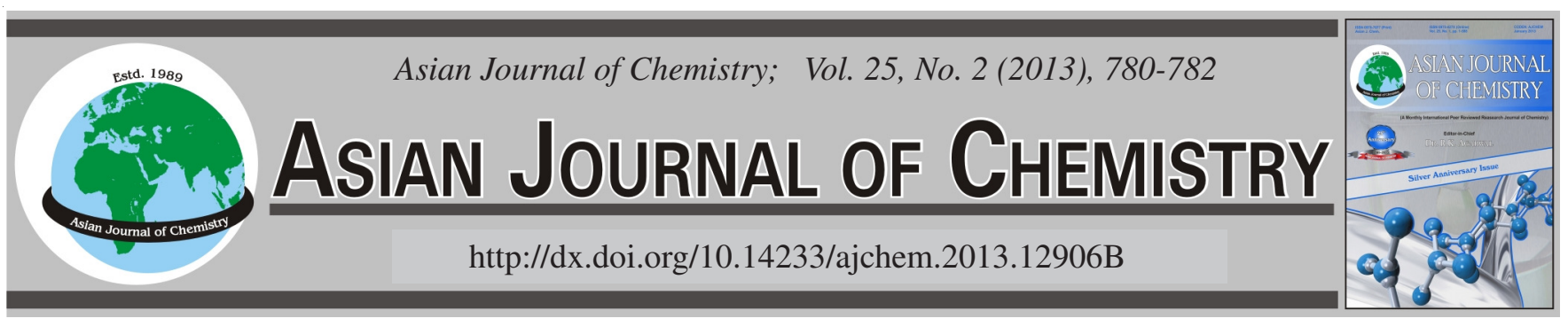

\title{
Synthesis and Structural Characterization of 4-Hydroxyanilinium 3,4,5,6-Tetrachloro-2-(methoxycarbonyl)benzoate Methanol Monosolvate
}

\author{
JIAN LI
}

Department of Chemistry and Chemical Engineering, Weifang University, Weifang 261061, P.R. China

Corresponding author: Tel: +86 536 8877561; E-mail: ljwfu@163.com

\begin{abstract}
The compound 4-hydroxyanilinium 3,4,5,6-tetrachloro-2-(methoxycarbonyl)benzoate methanol monosolvate $\left(\mathrm{C}_{16} \mathrm{H}_{15} \mathrm{Cl}_{4} \mathrm{NO}_{6}, \mathrm{M}_{\mathrm{r}}=459.09\right)$ was synthesized and characterized by single crystal X-ray diffraction. The crystal belongs to triclinic, space group P-1, with $\mathrm{a}=6.9729(7)$, $\mathrm{b}=10.7860(11), \mathrm{c}=13.5101(15) \AA, \beta=83.105(2)^{\circ}, \mathrm{V}=979.49(18) \AA^{3}, \mathrm{Z}=2, \mathrm{D}_{\mathrm{c}}=1.557 \mathrm{~g} / \mathrm{cm}^{3}, \lambda=0.71073 \AA, \mu\left(\mathrm{MoK}_{\alpha}\right)=0.637 \mathrm{~mm}^{-1}$, $\mathrm{F}_{(000)}=468$. The final refinement gave $\mathrm{R}=0.0991, \mathrm{wR}\left(\mathrm{F}^{2}\right)=0.2400$ for 3,338 observed reflections with $\mathrm{I}>2 \sigma(\mathrm{I})$. The asymmetric unit of the title compound contains one 4-hydroxyanilinium cation, one 3,4,5,6-tetrachloro-2-(methoxycarbonyl)benzoate anion and one methanol molecule. The two benzene rings are approximately parallel with a dihedral angle of $0.8(2)^{\circ}$. The components of the crystal are connected, via the intermolecular $\mathrm{N}-\mathrm{H} \cdots \mathrm{O}$ and $\mathrm{O}-\mathrm{H} \cdots \mathrm{O}$ hydrogen bonds interactions, to form network.
\end{abstract}

Key Words: 4-Hydroxyanilinium 3,4,5,6-tetrachloro-2-(methoxycarbonyl)benzoate, Monosolvate, Synthesis, Structure characterization.

ᄂ - - - - - - - - - - - - - - - - - - - - - - - - - -

\section{INTRODUCTION}

Phthalimides and N-substituted phthalimides are an important class of compounds because of their interesting biological activities ${ }^{1}$. Phthalimides have also served as starting materials and intermediates for the syntheses of alkaloids ${ }^{2}$ and pharmacophores ${ }^{3}$. Several N-substituted tetrachlorophthalimides have recently been synthesized and the study revealed $\mathrm{N}$-(2,4-dinitrophenyl)tetrachloro phthalimide could be a representative of a new group of $\alpha$-glucosidase inhibitors and exhibit significant antihyperglycemic effect ${ }^{4}$. In our previous work seveval intermediates, similar to the title compound, have been synthesized $d^{5-7}$. In this paper, the synthesis and the crystal structure of the title compound is reported.

\section{EXPERIMENTAL}

Synthesis of the title compound: All the reagents were of AR grade and used without further purification. A mixture of 4,5,6,7-tetrachloroisobenzofuran-1,3-dione (2.86 g, 0.01 $\mathrm{mol})$ and methanol $(15 \mathrm{~mL})$ was refluxed for $0.5 \mathrm{~h}$. And then 4-hydroxyaniline $(1.09 \mathrm{~g}, 0.01 \mathrm{~mol})$ was added to the above solution, being mixed round for $0.5 \mathrm{~h}$ at room temperature. The above solution was kept at room temperature for $5 \mathrm{~d}$. Natural evaporation gave colourless single crystals of the title compound, suitable for X-ray analysis.

Data collection and structure determination: A selected crystal of the title compound was mounted on a SMART CCD diffractometer. The reflection data were measured at $298 \mathrm{~K}$, using a graphite monochromator $\operatorname{MoK}_{\alpha}(\lambda=0.71073 \AA)$ radiation with an $\omega-2 \theta$ scan mode. The total reflections were 4,959 with 3,338 independent ones $\left(R_{\text {int }}=0.0462\right)$, of which 247 were observed with $\mathrm{I}>2 \sigma(\mathrm{I})$. Intensities were corrected for Lorentz and polarization effects and empirical absorption and all data were corrected using $\mathrm{SADABB}^{8}$ program.

The structure was solved by direct methods using SHELXS- $97^{9}$ program. All the non-hydrogen atoms were refined on $\mathrm{F}^{2}$ anisotropically by full-matrix least squares method. All hydrogen atoms were placed in the geometrically calculated positions. The contributions of these hydrogen atoms were included in the structurefactor calculations. The atomic scattering factors and anomalous dispersion corrections were taken from International Table for X-ray crystallography ${ }^{10}$. The final least-square cycle gave $\mathrm{R}=0.0991$ and $\omega \mathrm{R}=0.2400$ $\left(\mathrm{w}=1 /\left[\sigma^{2}\left(\mathrm{Fo}^{2}\right)+(0.1480 \mathrm{P})^{2}+0.0000 \mathrm{P}\right]\right.$, where $\mathrm{P}=\left(\mathrm{Fo}^{2}+\right.$ $\left.\left.2 \mathrm{Fc}^{2}\right) / 3\right) . \mathrm{S}=1.058,(\Delta \rho)_{\min }=-0.434$ and $(\Delta \rho)_{\max }=1.118 \mathrm{e} / \AA^{3}$. CIF file containing complete information on the studied structure was deposited with CCDC, deposition number 824539 and is freely available upon request from the following web site: www.ccdc.cam.ac.uk/data_request/cif

\section{RESULTS AND DISCUSSION}

In the present work, the reaction of 3,4,5,6-tetrabromo2-(methoxycarbonyl)benzoic acid and 4-hydroxyaniline in methanol is expected to form 4,5,6,7-tetrachloro-2-(4- 
hydroxyphenyl) isoindoline-1,3-dione, but instead formed the title compound. This may have happened because of the short time and cool temperature for the reaction.

The atomic coordinates and equivalent isotropic thermal parameters for the non-H atoms in the title compound are given in Table- 1 and the selected bond distances and bond angles in Table-2. A displacement ellipsoid plot with atomic numbering scheme is shown in Fig. 1 and a perspective view of the crystal packing in the unit cell in Fig. 2.

\begin{tabular}{|c|c|c|c|c|}
\hline \multicolumn{5}{|c|}{$\begin{array}{c}\text { TABLE-1 } \\
\text { ATOMIC COORDINATES }\left(\times 10^{4}\right) \text { AND } \\
\text { THERMAL PARAMETERS }\left(\AA^{2} \times 10^{3}\right)\end{array}$} \\
\hline Atom & $\mathrm{x}$ & $\mathrm{y}$ & $\mathrm{Z}$ & $\mathrm{U}(\mathrm{eq})$ \\
\hline $\mathrm{Cl}(1)$ & $2038(3)$ & $7559(2)$ & $9787(1)$ & $55(1)$ \\
\hline $\mathrm{Cl}(2)$ & $1528(3)$ & $10334(2)$ & $8629(2)$ & $60(1)$ \\
\hline $\mathrm{Cl}(3)$ & $1966(4)$ & $10789(2)$ & $6291(2)$ & $68(1)$ \\
\hline $\mathrm{Cl}(4)$ & $2555(4)$ & $8499(2)$ & $5135(2)$ & $73(1)$ \\
\hline $\mathrm{N}(1)$ & $7382(10)$ & $6069(5)$ & $9171(5)$ & $48(2)$ \\
\hline $\mathrm{O}(1)$ & $3789(13)$ & $5094(7)$ & $6468(5)$ & $96(3)$ \\
\hline $\mathrm{O}(2)$ & $987(15)$ & $5865(8)$ & $6001(7)$ & $116(3)$ \\
\hline $\mathrm{O}(3)$ & $4361(8)$ & $4962(5)$ & $8786(4)$ & $51(1)$ \\
\hline $\mathrm{O}(4)$ & $1222(8)$ & $4918(5)$ & $8756(4)$ & $58(2)$ \\
\hline $\mathrm{O}(5)$ & $6628(9)$ & $11027(5)$ & $7112(4)$ & $66(2)$ \\
\hline $\mathrm{O}(6)$ & $6846(10)$ & $2980(6)$ & $8010(5)$ & $76(2)$ \\
\hline $\mathrm{C}(1)$ & 2423(19) & $5913(10)$ & $6404(7)$ & $72(3)$ \\
\hline $\mathrm{C}(2)$ & $2702(13)$ & $5438(7)$ & $8558(5)$ & $43(2)$ \\
\hline $\mathrm{C}(3)$ & $2443(11)$ & $7028(7)$ & $6945(6)$ & $45(2)$ \\
\hline $\mathrm{C}(4)$ & $2428(11)$ & 6793(6) & $7984(5)$ & $39(2)$ \\
\hline $\mathrm{C}(5)$ & $2165(10)$ & $7825(7)$ & $8497(5)$ & $38(2)$ \\
\hline $\mathrm{C}(6)$ & 1961(10) & $9051(6)$ & $7982(6)$ & $40(2)$ \\
\hline $\mathrm{C}(7)$ & $2110(10)$ & $9269(6)$ & $6946(5)$ & $41(2)$ \\
\hline $\mathrm{C}(8)$ & $2318(12)$ & $8249(7)$ & $6424(6)$ & $47(2)$ \\
\hline $\mathrm{C}(9)$ & $3430(20)$ & 3931(11) & $6033(11)$ & $137(6)$ \\
\hline $\mathrm{C}(10)$ & $7195(10)$ & $7386(6)$ & $8643(5)$ & $39(2)$ \\
\hline $\mathrm{C}(11)$ & $6920(11)$ & $8378(7)$ & $9179(6)$ & $44(2)$ \\
\hline $\mathrm{C}(12)$ & $6723(11)$ & $9618(7)$ & $8687(6)$ & $48(2)$ \\
\hline $\mathrm{C}(13)$ & $6831(11)$ & $9841(7)$ & $7647(6)$ & $44(2)$ \\
\hline $\mathrm{C}(14)$ & $7083(11)$ & $8838(7)$ & $7107(6)$ & $45(2)$ \\
\hline$C(15)$ & $7253(11)$ & 7611(7) & $7618(6)$ & $45(2)$ \\
\hline $\mathrm{C}(16)$ & $8271(17)$ & $3559(10)$ & 7397(9) & $93(4)$ \\
\hline
\end{tabular}

TABLE-2

SELECTED BOND LENGTHS $(\AA)$ AND BOND ANGLES $\left(^{\circ}\right)$

\begin{tabular}{cccc}
\hline Bond & Length $(\AA)$ & Bond & Angle $\left(^{\circ}\right)$ \\
\hline $\mathrm{Cl}(1)-\mathrm{C}(5)$ & $1.711(7)$ & $\mathrm{C}(1)-\mathrm{O}(1)-\mathrm{C}(9)$ & $110.7(10)$ \\
$\mathrm{Cl}(2)-\mathrm{C}(6)$ & $1.722(7)$ & $\mathrm{O}(1)-\mathrm{C}(1)-\mathrm{O}(2)$ & $123.8(11)$ \\
$\mathrm{Cl}(3)-\mathrm{C}(7)$ & $1.715(7)$ & $\mathrm{O}(1)-\mathrm{C}(1)-\mathrm{C}(3)$ & $116.3(11)$ \\
$\mathrm{Cl}(4)-\mathrm{C}(8)$ & $1.709(8)$ & $\mathrm{O}(2)-\mathrm{C}(1)-\mathrm{C}(3)$ & $119.7(10)$ \\
$\mathrm{N}(1)-\mathrm{C}(10)$ & $1.465(8)$ & $\mathrm{O}(3)-\mathrm{C}(2)-\mathrm{O}(4)$ & $126.1(7)$ \\
$\mathrm{O}(1)-\mathrm{C}(1)$ & $1.174(11)$ & $\mathrm{O}(3)-\mathrm{C}(2)-\mathrm{C}(4)$ & $117.0(7)$ \\
$\mathrm{O}(1)-\mathrm{C}(9)$ & $1.546(13)$ & $\mathrm{O}(4)-\mathrm{C}(2)-\mathrm{C}(4)$ & $116.9(7)$ \\
$\mathrm{O}(2)-\mathrm{C}(1)$ & $1.209(13)$ & $\mathrm{C}(8)-\mathrm{C}(3)-\mathrm{C}(4)$ & $121.1(7)$ \\
$\mathrm{O}(3)-\mathrm{C}(2)$ & $1.228(9)$ & $\mathrm{C}(8)-\mathrm{C}(3)-\mathrm{C}(1)$ & $120.8(7)$ \\
$\mathrm{O}(4)-\mathrm{C}(2)$ & $1.244(9)$ & $\mathrm{C}(4)-\mathrm{C}(3)-\mathrm{C}(1)$ & $117.9(7)$ \\
$\mathrm{O}(5)-\mathrm{C}(13)$ & $1.348(8)$ & $\mathrm{C}(5)-\mathrm{C}(4)-\mathrm{C}(2)$ & $120.3(6)$ \\
$\mathrm{O}(6)-\mathrm{C}(16)$ & $1.384(12)$ & $\mathrm{C}(15)-\mathrm{C}(10)-\mathrm{N}(1)$ & $119.4(6)$ \\
$\mathrm{C}(1)-\mathrm{C}(3)$ & $1.514(12)$ & $\mathrm{C}(11)-\mathrm{C}(10)-\mathrm{N}(1)$ & $120.1(6)$ \\
$\mathrm{C}(2)-\mathrm{C}(4)$ & $1.522(10)$ & $\mathrm{O}(5)-\mathrm{C}(13)-\mathrm{C}(12)$ & $122.6(7)$ \\
- & - & $\mathrm{O}(5)-\mathrm{C}(13)-\mathrm{C}(14)$ & $116.8(7)$ \\
\hline
\end{tabular}

As seen from Fig. 1, the asymmetric unit of the title compound contains one 4-hydroxyanilinium cation, one 3,4,5,6tetrachloro-2-(methoxycarbonyl)benzoate anions and one methanol molecules. The two benzene rings are approximately parallel with a dihedral angle of $0.8(2)^{\circ}$. In the anion, the mean

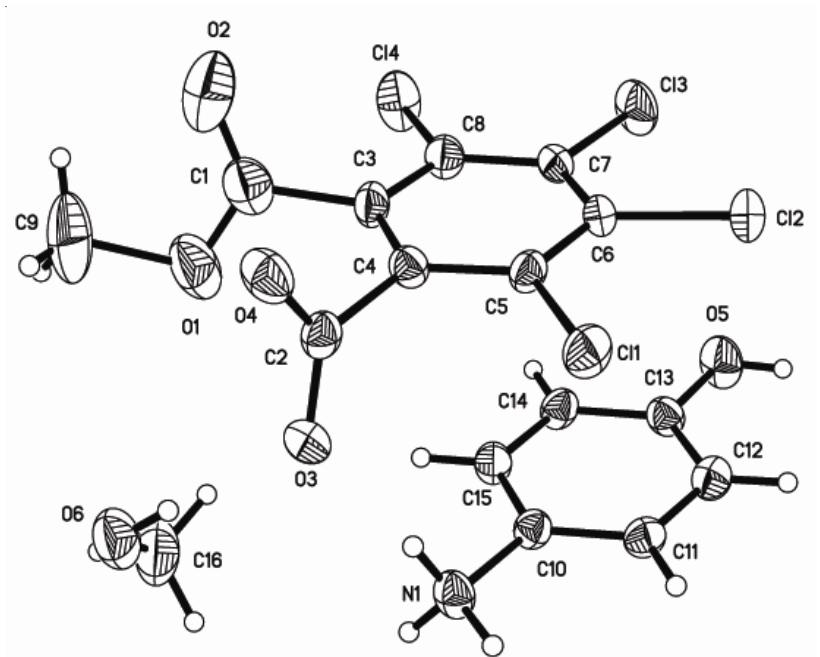

Fig. 1. Molecular structure with atomic numbering scheme

planes of the methoxycarbonyl and carboxylate groups form dihedral angles of 65.4(3) and 48.9(3) ${ }^{\circ}$, respectively with the benzene ring. The bond lengths and angles are in agreement with those in cyclohexanaminium 3,4,5,6-tetrachloro-2(methoxycarbonyl)benzoate ${ }^{6}$ and hexane-1,6-diaminium 3,4,5,6-tetrachloro-2-(methoxycarbonyl) benzoate ${ }^{7}$. As seen from Fig. 2 and Table-3, the crystal structure of the title compound is stabilized by $\mathrm{N}-\mathrm{H} \cdots \mathrm{O}$ and $\mathrm{O}-\mathrm{H} \cdots \mathrm{O}$ hydrogen bonds interactions. Fig. 2 reveals that in the crystal the components of the title compound are connected, via the intermolecular hydrogen bonds interactions, to form network.

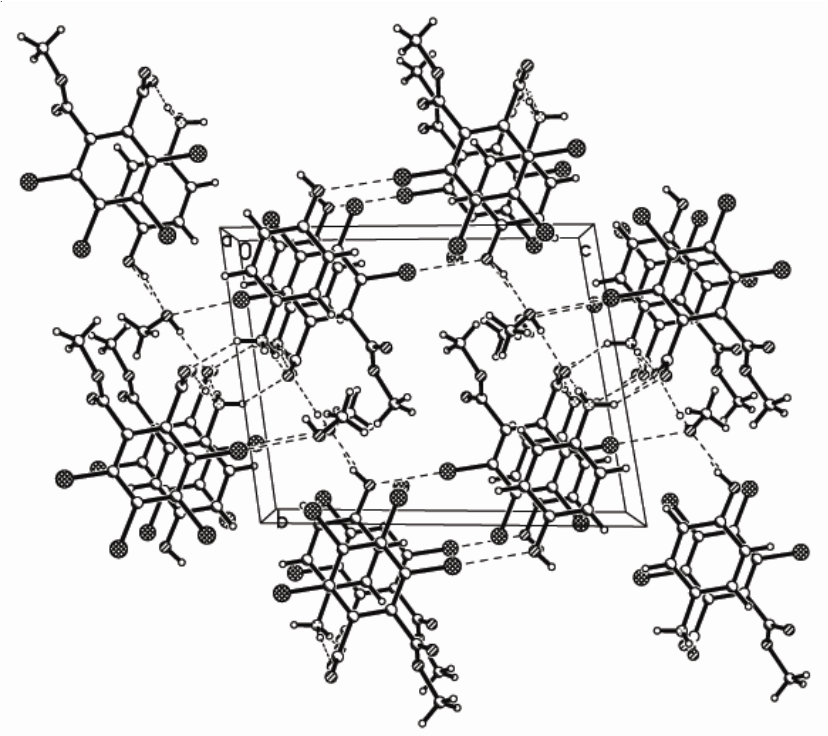

Fig. 2. View of crystal packing down the a-axis

\begin{tabular}{|c|c|c|c|c|}
\hline \multicolumn{5}{|c|}{$\begin{array}{c}\text { TABLE-3 } \\
\text { HYDROGEN BOND SCHEMES }\left(\AA{ }^{\circ}{ }^{\circ}\right)\end{array}$} \\
\hline D-H $\cdots A$ & D-H & $\mathrm{H} \cdots \mathrm{A}$ & D-A & D-H $\cdots A$ \\
\hline N1-H1A $\cdots \mathrm{O} 3$ & 0.89 & 1.86 & 2.75 & 172 \\
\hline $\mathrm{N} 1-\mathrm{H} 1 \mathrm{~B} \cdots \mathrm{O} 3^{\mathrm{a}}$ & 0.89 & 2.36 & 2.99 & 128 \\
\hline $\mathrm{N} 1-\mathrm{H} 1 \mathrm{~B} \cdots \mathrm{O} 4^{\mathrm{a}}$ & 0.89 & 2.24 & 3.03 & 148 \\
\hline $\mathrm{N} 1-\mathrm{H} 1 \mathrm{C} \cdots \mathrm{O} 4^{\mathrm{b}}$ & 0.89 & 1.93 & 2.77 & 156 \\
\hline O5-H5 $\cdots \mathrm{O}^{\mathrm{c}}$ & 0.82 & 1.87 & 2.64 & 156 \\
\hline O6-H6 ‥ 33 & 0.82 & 1.95 & 2.77 & 173 \\
\hline
\end{tabular}




\section{ACKNOWLEDGEMENTS}

This work was supported by Shandong Provincial Natural Science Foundation, China (No. ZR2009BL027).

\section{REFERENCES}

1. L.M. Lima, P. Castro, A.L. Machado, C.A.M. Frage, C. Lugniur, V.L.G. Moraes and E. Barreiro, J. Biol. Org. Med. Chem., 21, 3067 (2002).

2. A. Couture, E. Deniau, P. Grandclaudon and C. Hoarau, J. Org. Chem., 63, 3128 (1998).

3. A. Couture, E. Deniau, P. Woisel and P. Grandclaudon, Synth.-Stuttgart, 12, 1439 (1997)
4. S. Mahapatra, J. Singh, R. Raju, B.C. Maiti and T.K. Maity, Asian J. Chem., 23, 1581 (2011).

5. Z.P. Liang and J. Li, Asian J. Chem., 25, 657 (2013).

6. J. Li, Acta Cryst., E67, o842 (2011)

7. J. Li, Acta Cryst., E67, o901 (2011).

8. G.M. Sheldrick, SADABS, Program for Empirical Absorption Correction of Area Detector Data, University of Gottingen, Germany (1996).

9. G.M. Sheldrick, SHELXTL V 5.1 Software Reference Manual, Bruker AXS, Inc., Madison, Wisconsin, USA (1997).

10. Siemens, SMART and SAINT, Area Detector Control and Integration Software. Siemens Analytical X-Ray Systems, Inc., Madison, Wiscon$\sin$, USA (1996). 